\title{
THE INFLUENCE OF SERVICE SOLUTIONS ON LONGITUDINAL AND CIRCUMFERENTIAL TENSILE PROPERTIES OF GLASS-POLYESTER COMPOSITE PIPES
}

\author{
M. STAMENOVIĆ ${ }^{1}$, S. PUTIĆ ${ }^{2}$, S. DRMANIĆ ${ }^{2}$, M. RAKIN ${ }^{2}$, B. MEDJO ${ }^{2}$ \\ ${ }^{1}$ Belgrade Polytechnic, Serbia; \\ ${ }^{2}$ Faculty of Technology and Metallurgy, Belgrade, Serbia
}

\begin{abstract}
Traditionally used metals and alloys as constructive materials in process equipment can nowadays be successfully replaced in many cases by non-metallic composite materials. The influence of service solutions on the state of stress and tensile properties in longitudinal and circumferential direction of glass-polyester pipes is studied in this paper. These analyses are of great importance for the use of examined pipes in chemical industry. The pipes were produced by Corporation "Poliester" Priboj. The influence of two solutions, methanol and ammonia, was studied. The samples were treated in solutions for three, seven and ten days. After that, the samples were subjected to tensile testing by the standard procedure. The stresses and strengths were determined in longitudinal direction (testing on flat test specimens) and in circumferential direction (ring test). The analysis of test results, according to the type of solution and period of exposure, was done in comparison with the results obtained by virgin pipes testing (without the influence of the solution). Micromechanical analysis on broken samples helped to determine the influence of the solution on the structure of composite pipe and to find out the models and mechanisms which produced decrease of strength.
\end{abstract}

Keywords: glass-polyester composite pipe, tension test, ring test, influence of solution, micromechanical analysis.

Intensive development of polymer engineering, as well as capabilities of polymers in combination with other materials to form new, synthetic structures of improved mechanical properties, led to a real expansion in use of composite materials, followed by continuous improvement of technology of their manufacturing and application. Composite materials have a wide range of usage, thanks to their good properties under external loading, specific mechanisms of cracking and capability for accumulation of energy, and they pose the greatest competition to the classical construction materials. The advantages are: relatively small mass, good balance strength/mass and stiffness/ mass, good static and dynamic properties, good resistance to corrosion, simplified fabrication and time of assembling.

All stated advantages led to the fact that composite pipes are very much used today in chemical, building, infrastructure and military industry. An important use of pipes made of composites glass fibres-polyester resin is in chemical industry. Pipes made for this usage are, during their exploitation, subjected to the influence of static and dynamic loading. Considering the conditions of possible exploitation in chemical industry, the subject of this paper is the determination of the influence of solution, as fluid which is transported through the glass-polyester composite pipes, on their tensile properties in longitudinal and circumferential direction.

Different structure of composite pipes causes different distribution of stress, and the development of failure after the initiation of the first cracks. In the last few decades,

Corresponding author: M. RAKIN, e-mail: marko@tmf.bg.ac.rs 
many researchers have been conducting these investigations. Special attention was always given to determination of stress conditions in longitudinal and circumferential direction. The radial-cut method and ring test give the best results for pipes. The radialcut method is a simple, inexpensive and approximate method of determining the residual stress state in a cylindrical part. In this method the ring is cut in the radial direction to release the residual stresses. Measurement of the subsequent deformation of the ring in the circumferential and radial direction gives an indication of the magnitude of the stresses present prior to the cut. Aleong and Munro [1] used this method to determine the residual stresses in radially-thick filament-wound composite rings. In their experiments the rings were cut along the radius and the radial and circumferential strains in the rings were measured using resistive gauges. Aleong and Munro [1] performed the radial cut method on eight E/XA-S Grafil carbon and three S2-glass fibre-epoxy matrix composite rings with outside to inside diameter ratios of approximately 1.22 to 1.30. The aim of the study presented in [2] was to characterize the influence of structure on mechanical performance of cylindrical geometries under various loadings. The studied specimens were glass-epoxy tubes with a $\left[ \pm 55^{\circ}\right]_{6}$ lay-up. All manufacturing parameters were kept constant, except for the winding pattern. Quality of fabrication was assessed by strict monitoring of the geometry and microstructure of the tubes. Tests carried out on the specimens consisted in progressive repeated loadings, aimed at characterizing the damage behaviour under different loading conditions. Micro-structural analysis, mechanical behaviour and damage mechanisms of composite tubes under pure tensile loading are presented in [3]. Tests were performed on $\pm 55^{\circ}$ filamentwound glass fibre-epoxy resin tubes.

The effects of hydrochloric acid $(\mathrm{HCl})$, sulphuric acid $\left(\mathrm{H}_{2} \mathrm{SO}_{4}\right)$, nitric acid $\left(\mathrm{HNO}_{3}\right)$ and phosphoric acid $\left(\mathrm{H}_{3} \mathrm{PO}_{4}\right)$ on the mechanical properties of glass-polyester composite pipes internally lined with $\mathrm{C}$ glass were studied in [4]. Specimens cut from the pipes were immersed for various periods - 30, 60, and 90 days in $20 \%$ acid concentration at room temperature and $100^{\circ} \mathrm{C}$. The effects of sulphuric acid concentration and the sequential lay-up of glass fibre reinforcements on the diffusion behaviour of glassepoxy composite laminates were studied in [5]. Experimental results for the direct effect of an acidic stress environment on the stress intensity factor of woven E-glass fibre reinforced bisphenol-vinylester resin, woven E-glass fibre reinforced bisphenolepoxy resin and woven C-glass fibre reinforced bisphenol-vinylester resin composites are presented in [6]. The influence of different conditions on the mechanical properties of coir fibre reinforced polymer composites, as well as glass fibre reinforced polymer composites have been analyzed and compared in [7]. Degradation was studied in different solutions, like $10 \% \mathrm{NaOH}, 1 \mathrm{~N} \mathrm{HCl}, 10 \% \mathrm{NaCl}$ and water. The effect of these solutions and water on mechanical properties of the composites was studied in detail. The deterioration of mechanical properties of the composites by environmental weathering was also studied.

Experimental procedures. Composite pipes have been fabricated in the lab conditions, by Corporation "Poliester" Priboj. The properties are given in official certificates from the producers of components of used glass-polyester pipes. The producers of glass fibres, "OHIS" Skopje and "Vidoe Smilevski-Bato" Gostivar, by their certificate confirm "E" glass with $1 \%$ of alkali (Tables 1 and 2). Thermo-reactive polyester resin produced by "Color" Medvode was used as matrix. Certificate was given for "COLPOLY 7510" for the type: UP/SOM- highly reactive, low viscosity polyester on the basis of ortoftaly acid in standard glycol (Table 3 ).

The pipes were made by the method "filament winding" with angle of glass fibres reinforcement $\left[90^{\circ}\right]_{2}\left[ \pm 55^{\circ}\right]_{4}\left[90^{\circ}\right]_{4}$. The specimens for tests (flat specimens and rings) were cut from the samples of pipes according to the standard dimensions, the flat specimens $250 \times 25(20$ gage area $) \times 3.5 \mathrm{~mm}$, and the rings of diameter $\varnothing 70 \times 35 \times 3.5 \mathrm{~mm}$ (ave- 
rage values for all tested samples). The cutting was performed on machine type NC-2010 ( $\mathrm{Nr} 95110, \mathrm{Ar}$ 001) using the tools with diamond top and the speed of moving which reduces the heat in the sample.

Table 1. Structural components of "E"-glass

\begin{tabular}{|c|c|}
\hline Structural component & Percentage, $\%$ \\
\hline Silicon (IV) oxide & $52 \ldots 56$ \\
\hline Aluminum (III) oxide & $12 \ldots 16$ \\
\hline Boron (III) oxide & $5 \ldots 10$ \\
\hline $\begin{array}{c}\text { Sodium (I) oxide, } \\
\text { Potassium (I) oxide }\end{array}$ & $0 \ldots 2$ \\
\hline Magnesium (II) oxide & $0 \ldots 5$ \\
\hline Calcium (II) oxide & $16 \ldots .25$ \\
\hline Titan (IV) oxide & $0 \ldots 1.5$ \\
\hline Iron (III) oxide & $0 \ldots 0.8$ \\
\hline Iron & $0 \ldots 1$ \\
\hline
\end{tabular}

Table 2. Physical properties of "E"-glass fibre

\begin{tabular}{|c|c|}
\hline \multicolumn{2}{|c|}{ Properties } \\
\hline Specific weight & $2.54 \mathrm{~g} / \mathrm{cm}^{3}$ \\
\hline Tensile strength & $2400 \mathrm{MPa}$ \\
\hline Modulus of elasticity & $73 \mathrm{GPa}$ \\
\hline Extension & $3.3 \%$ \\
\hline Thermal expansion & $5 \cdot 10^{-6} \mathrm{~K}^{-1}$ \\
\hline Thermal conductivity & $1 \mathrm{~W} / \mathrm{mK}$ \\
\hline Dielectrical constant $\xi$ & 6.7 \\
\hline Specific electrical resistance & $10^{14} \Omega \cdot \mathrm{cm}$ \\
\hline Moisture absorption at $20^{\circ} \mathrm{C}$ & $0.1 \%$ \\
\hline
\end{tabular}

Table 3. Catalog properties of polyester resin

\begin{tabular}{|c|c|}
\hline Properties & Specification \\
\hline Appearance & Viscous yellow liquid \\
\hline Density & $1.11 \ldots 1.21 \mathrm{~g} / \mathrm{cm}^{3}$ \\
\hline Viscosity at $25^{\circ} \mathrm{C}$ & $220 \ldots 320 \mathrm{mPa} \cdot \mathrm{s}$ \\
\hline Specific weight & $1.19 \ldots 1.21 \mathrm{~g} / \mathrm{cm}^{3}$ \\
\hline Tensile strength & $75 \ldots 85 \mathrm{MPa}$ \\
\hline Modulus of elasticity & $3.6 \mathrm{GPa}$ \\
\hline Extension & $2 \ldots 3 \%$ \\
\hline Impact toughness /Charpy/ & $10 \ldots 15 \mathrm{~kJ} / \mathrm{m}^{2}$ \\
\hline
\end{tabular}

Some of the tested samples were not exposed to solutions (five test specimens), while the others were exposed to two types of solutions (three test specimens for each of the three periods - three, seven and ten days). The pipes were exposed to solutions on the inner side (they were filled with solutions). From the group of organic solvents methanol was used $\left(\mathrm{CH}_{3} \mathrm{OH}\right.$, p.a.) as $25 \%$ solution; while from the group of non-organic solvents ammonium hydroxide was chosen $\left(\mathrm{NH}_{4} \mathrm{OH}\right.$, p.a.), as $25 \%$ solution too. These solutions (in the remainder of the text these are denoted as methanol and ammonium hydroxide) were chosen according to the researches which showed that the mass of the pipe samples changed significantly by exposing to them [8]. After the mentioned time of exposure, the process of drying started. Test tubes were dried in the electrical drying machine at a temperature of $30^{\circ} \mathrm{C}$ for $2 \mathrm{~h}$.

Testing of flat test specimens was performed on servo-hydraulic testing machine SCHENCK TREBEL RM 100, and ring test on servo-hydraulic testing machine INSTRON 1332, using an INSTRON FAST TRACK 80800 controller and hydraulic jaws. The testing was defined by the standard ASTM D 3039 [9] for flat specimens and ASTM D 2290 [10] for ring specimens. Loading was registered using a measuring cell 
with capacity of $100 \mathrm{kN}$. Displacements were measured by double extensometer HOTTINGER DD1. During the test, force-elongation $(\Delta P / \Delta l)$ diagrams were plotted.

Test results and discussion. Tensile strength $R_{m}(\mathrm{MPa})$ was calculated according to Eq. 1 in longitudinal direction for flat test specimens, and according to Eq. 2 for the rings in circumferential direction:

$$
\begin{gathered}
R_{m, l}=\frac{P_{\max }}{b_{l} \cdot d}, \\
R_{m, c}=\frac{P_{\max }}{2 \cdot b_{c} \cdot d},
\end{gathered}
$$

where $P_{\max }(\mathrm{kN})$ is the maximum applied force; $b(\mathrm{~mm})$ is the width of the flat test specimen; $b_{c}(\mathrm{~mm})$ is the width of the ring test specimen; $d(\mathrm{~mm})$ is the thickness of the test specimens (flat specimens or rings) - subscripts $l$ and $c$ stand for longitudinal and circumferential direction in the remainder of the text.

Modulus of elasticity $E(\mathrm{GPa})$ was calculated by the method of linear regression from rectilinear parts of the force-elongation $(\Delta P / \Delta l)$ curves obtained directly from the testing machine.

$$
E_{l}=\frac{\Delta \sigma}{\Delta \varepsilon}=\frac{\Delta P}{\Delta \varepsilon} \cdot \frac{1}{b_{l} \cdot d} ; \quad E_{c}=\frac{\Delta \sigma}{\Delta \varepsilon}=\frac{\Delta P}{\Delta \varepsilon} \cdot \frac{1}{2 \cdot b_{c} \cdot d} .
$$

According to the period of exposure to solutions, as well as the solution type, average obtained results for tensile strength and modulus of elasticity in both directions are presented in Tables 4 and 5. Comparison of these values in circumferential and longitudinal direction, according to the type of solution and number of days of exposure, are presented in Fig. 1.
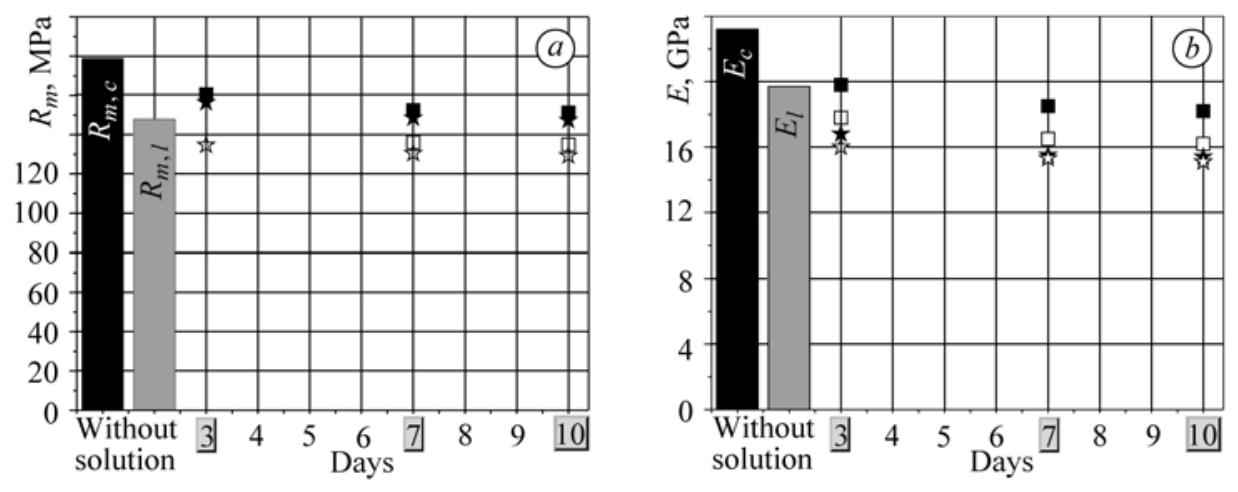

Fig. 1. Comparison of average values of tensile strength $(a)$ and modulus of elasticity $(b)$ in circumferential and longitudinal direction, according to the solution type and period of exposure: - circumferential, $\square$ - longitudinal (methanol); $\star$ - circumferential, $\downarrow$ - longitudinal (ammonium hydroxide).

It can be concluded that there is no progressive decrease of tensile strength with the number of days for which the samples were exposed to the solutions. For tensile strength after three days, decrease is $3.8 \%$ for longitudinal direction and $10.3 \%$ for circumferential direction with methanol, $9.0 \%$ for longitudinal direction and $12.6 \%$ for circumferential direction with ammonium hydroxide. After that a decrease of values also exists, but it is considerably smaller: $8.0 \%$ for seven and $8.7 \%$ for ten days in longitudinal direction and $14.7 \%$ and $15.4 \%$ in circumferential direction with methanol; $11.8 \%$ for seven and $12.6 \%$ for ten days in longitudinal direction and $17.0 \%$ and $17.7 \%$ in circumferential direction with ammonium hydroxide. From Tables 4 and 5, Fig. 1, 
and also from previous discussion, it can be concluded that both solutions reduce tensile strength in both directions. When comparing the two solutions, the influence of ammonium hydroxide on reducing is more prominent. Also the greatest tensile strength reduction in both cases appeared after the first seven days and after that reduction in the next three days (up to ten days) decreases: $0.7 \%$ in both directions with methanol, and $0.8 \%$ in longitudinal direction and $0.7 \%$ in circumferential direction with ammonium hydroxide.

Table 4. Average values of tensile strength and modulus of elasticity in longitudinal direction

\begin{tabular}{|c|c|c|c|c|c|}
\hline Solution & $\begin{array}{c}\text { Number } \\
\text { of days }\end{array}$ & $\begin{array}{c}\text { Tensile strength }- \\
\text { average value, } \\
R_{m, l}, \mathrm{MPa}\end{array}$ & $\begin{array}{c}\text { Change, } \\
\%\end{array}$ & $\begin{array}{c}\text { Modulus of } \\
\text { elasticity - average } \\
\text { value, } E_{l}, \mathrm{GPa}\end{array}$ & $\begin{array}{c}\text { Change, } \\
\%\end{array}$ \\
\hline $\begin{array}{c}\text { Without } \\
\text { solution }\end{array}$ & - & 147.9 & - & 19.7 & - \\
\hline \multirow{4}{*}{ Methanol } & 3 & 142.2 & 3.8 & 17.8 & 9.6 \\
\cline { 2 - 6 } & 7 & 136.1 & 8.0 & 16.5 & 16.2 \\
\cline { 2 - 6 } & 10 & 135.0 & 8.7 & 16.2 & 17.8 \\
\hline \multirow{2}{*}{$\begin{array}{c}\text { Ammonium } \\
\text { hydroxide }\end{array}$} & 3 & 134.6 & 9.0 & 16.0 & 18.8 \\
\cline { 2 - 6 } & 7 & 130.5 & 11.8 & 15.3 & 22.3 \\
\hline
\end{tabular}

Table 5. Average values of tensile strength and modulus of elasticity in circumferential direction

\begin{tabular}{|c|c|c|c|c|c|}
\hline Solution & $\begin{array}{c}\text { Number } \\
\text { of days }\end{array}$ & $\begin{array}{c}\text { Tensile strength }- \\
\text { average value, } \\
R_{m, c}, \mathrm{MPa}\end{array}$ & $\begin{array}{c}\text { Change, } \\
\%\end{array}$ & $\begin{array}{c}\text { Modulus of } \\
\text { elasticity - average } \\
\text { value, } E_{c}, \mathrm{GPa}\end{array}$ & $\begin{array}{c}\text { Change, } \\
\%\end{array}$ \\
\hline $\begin{array}{c}\text { Without } \\
\text { solution }\end{array}$ & - & 178.9 & - & 23.2 & - \\
\hline \multirow{4}{*}{ Methanol } & 3 & 160.5 & 10.3 & 19.8 & 14.7 \\
\cline { 2 - 6 } & 7 & 152.5 & 14.7 & 18.5 & 20.3 \\
\cline { 2 - 6 } & 10 & 151.3 & 15.4 & 18.2 & 21.6 \\
\hline \multirow{2}{*}{$\begin{array}{c}\text { Ammonium } \\
\text { hydroxide }\end{array}$} & 3 & 156.4 & 12.6 & 16.8 & 27.6 \\
\cline { 2 - 6 } & 7 & 148.5 & 17.0 & 15.5 & 33.2 \\
\hline
\end{tabular}

However, both solutions caused greater decrease in values for modulus of elasticity, and also a decrease of stiffness. After three days, this decrease is $9.6 \%$ for longitudinal direction and $14.7 \%$ for circumferential direction with methanol, and $18.8 \%$ for longitudinal direction and $27.6 \%$ for circumferential direction with ammonium hydroxide. After that, the decrease of values also exists, but it is considerably smaller: $16.2 \%$ for seven and $17.8 \%$ for ten days in longitudinal direction and $20.3 \%$ and $21.6 \%$ in circumferential direction with methanol; $22.3 \%$ for seven and $23.4 \%$ for ten days in longitudinal direction and $33.2 \%$ and $33.6 \%$ in circumferential direction with ammonium hydroxide. Just like for tensile strength, a decrease of modulus of elasticity (stiffness) under the influence of both solutions is also evident in this case, with higher reduction for ammonium hydroxide. Also the greatest tensile strength reduction in both cases 
appeared after the first seven days, and after that reduction in the next three days (up to ten days) decreases: $1.6 \%$ in longitudinal direction and $1.3 \%$ in circumferential direction with methanol, and $1.1 \%$ in longitudinal direction and $0.4 \%$ in circumferential direction with ammonium hydroxide.

Results have shown a slight loss: for the tensile strength it is low, while for the modulus of elasticity it is somewhat higher. This stands for both directions and solutions, and the explanation are models and mechanisms of cracking which were similar. Because of that, the analysis of results can be conducted according to the reinforcement which, on the one hand, gives the material strength and stiffness, and on the other (due to its specific properties) leads to different models of crack initiation and propagation. This is very important because of the pipe structure, which produced different distribution of strains in layers, and fibres were not loaded in the same way.

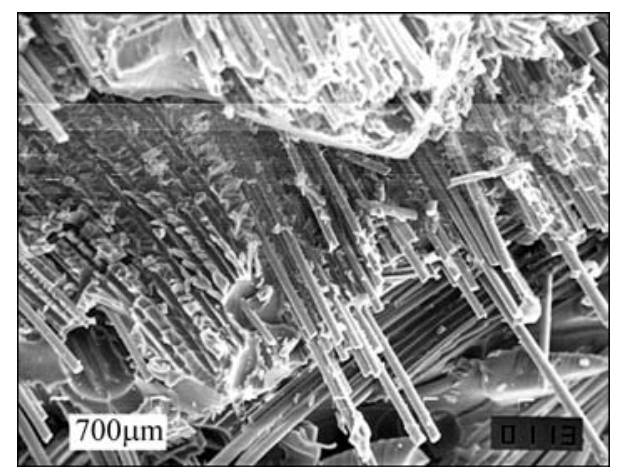

Fig. 2. SEM micrograph of the first broken fibres.

Fibres that broke earlier (Fig. 2) caused the disturbance in the zone of the crack, that is, local shear stresses appeared causing the fibre pullout mechanism.

Important contribution of shear components of strain can be seen from the obtained stress-strain $(\sigma-\varepsilon)$ curves, which were not linear, unlike the most composites. With the increase of loading, there was cracking by fibre-matrix debonding, and the crack which was initiated by breaking of fibres was growing along neighbouring fibres and caused a macrocrack (Fig. 3).
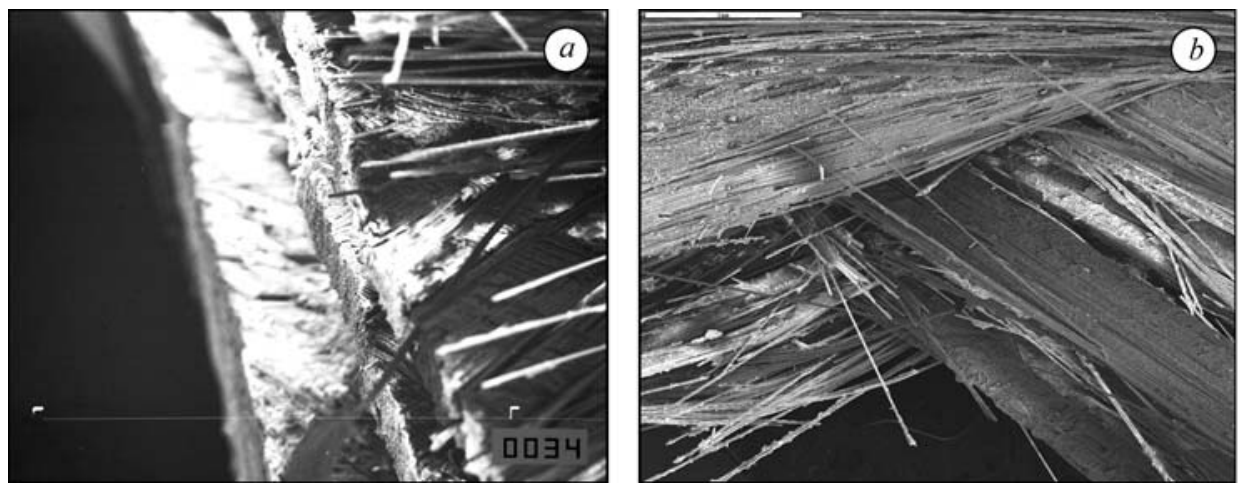

Fig. 3. Macro-crack SEM micrograph of a flat $(a)$ and of a ring $(b)$ specimen.

The result was local cracking of fibres and whole layers (Fig. 4), but the composite still carried the external load. With the increase of loading, local failures started spreading, and the final crack appeared with a strong acoustic effect, as a consequence of simultaneous cracking of many fibres. The fibres were cracked chaotically in all directions.

Delamination of layers is certainly the following phenomenon of damage for all tested specimens. The surface of delamination has the appearance which is proper for the surfaces made under interlaminar shear stress along the surface of contact fibrematrix. 

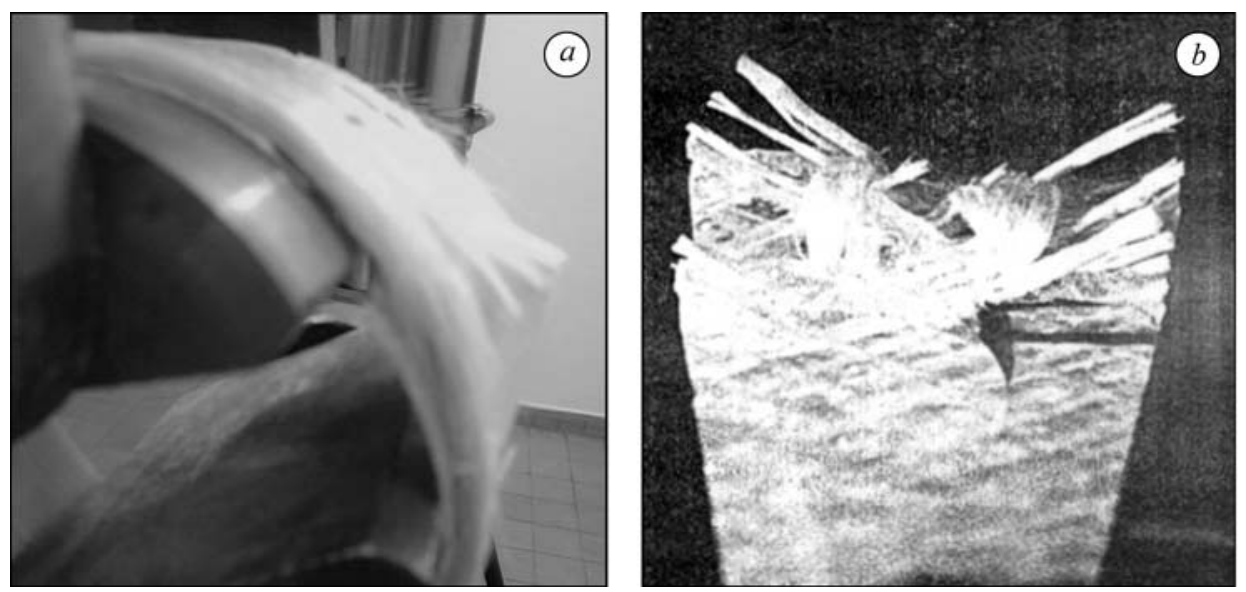

Fig. 4. The view of local cracking of fibres and whole layers on ring $(a)$ and flat $(b)$ specimen.

\section{CONCLUSION}

It was established by testing of the flat specimens and rings cut from glass-polyester composite pipes that the exposure to service solutions causes decrease of their tensile strength and stiffness in longitudinal and circumferential directions. Decrease in elasticity modulus is more pronounced in comparison with the tensile strength in all cases; in the circumferential direction, much more severe loss of stiffness is observed under the influence of ammonium-hydroxide (33.6\%; while for methanol this difference is $21.6 \%$ ). This represents an unfavourable influence, having in mind that the pipes are exploited in the elastic loading regime without reaching the tensile strength (controlled by appropriate safety factors).

Decrease of strength and stiffness suggests that absorption of the solution, as well as dissolving of the polymer matrix in the solution, occurred on the inner surface of the pipes. In this way, with decrease of quantity of resin there was an increased number of micro-cracks in pipes and weakening of the fibre-matrix bond where micro-cracks were initiated and large strain concentration occurred. The loss of resin went from the inner surface of the pipe, considering that this surface was exposed to solutions. Degradation of the fibre-matrix interface is caused by matrix dehidratation, as well as penetration of the solutions through microcracks into the pipe structure. It is observed that the fibres were not drastically damaged due to the exposure to solutions. Decrease of strength and stiffness during the first three days is the most prominent, which suggests that damage processes are the most intensive during this period.

РЕЗЮМЕ. Композиційні матеріали - перспективні замінники металів та сплавів, які традиційно використовують для виготовлення технологічного обладнання хімічної промисловості. Вивчено вплив розчинів метанолу та аміаку на напруження та механічні властивості склополіефірних труб за їх розтягу в поздовжньому та круговому напрямках. Плоскі та кільцеподібні зразки вирізали із труб та випробовували на розтяг за стандартною методикою. Одержані результати порівнювали з даними для труб у вихідному стані. За допомогою мікромеханічного аналізу зруйнованих зразків встановлено характер впливу розчинів на структуру композиційної труби. Розкрито особливості механізму зниження іiї міцності.

РЕЗЮМЕ. Композиционные материалы - перспективные заменители металлов и сплавов, которые традиционно используют для изготовления технологического оборудования химической промышленности. Изучено влияние растворов метанола и аммиака на напряжение и механические свойства стеклополиэфирных труб при их растяжении в продольном и круговом направлениях. Плоские и кольцевидные образцы вырезали из труб и испытывали на растяжение по стандартной методике. Полученные результаты сравнивали 
с данными для труб в исходном состоянии. С помощью микромеханического анализа разрушенных образцов установлен характер влияния растворов на структуру композиционной трубы. Раскрыты особенности механизма снижения ее прочности.

Acknowledgements. The authors would like to thank to the Corporation "Poliester" Priboj for the glass-polyester pipes. SP, MR and BM acknowledge the support from the Serbian Ministry of Science under the project OI 174004.

1. Aleong C. and Munro M. Evaluation of radial-cut method for determining residual strains in fiber composite rings // Experimental Techniques. - 1991. - 15, № 1. - P. 55-58.

2. Rousseaua J., Perreux D., and Verdiere N. The influence of winding patterns on the damage behaviour of filament-wound pipes // Composites Scien. and Technol. - 1999. - 59, № 9. - P. 1439-1449.

3. Bai L., Seeleuthner P., and Bompard P. Mechanical behaviour of $\pm 55^{\circ}$ filament-wound glass-fibre/epoxy-resin tubes: I. Micro-structural analyses, mechanical behaviour and damage mechanisms of composite tubes under pure tensile loading, pure internal pressure, and combined loading // Ibid. - 1997. - 57, № 2. - P. 141-153.

4. Mahmoud K. M. and Tantawi S. H. Effect of strong acids on mechanical properties of glass/ polyester grp pipe at normal and high temperatures // Polymer-Plastics Technology and Engn. - 2003. - 42, № 4. - P. 677-688.

5. Pai R., Kamath M. S., and Rao R. M. V. G. K. Acid resistance of glass fiber composites with different layup sequencing. Part I - diffusion studies // J. Reinforced Plastics and Composites. - 1997. - 16, № 11. - P. 1002-1012.

6. Hiroyuki K. and Srivastava $V . K$. The effect of an acidic stress environment on the stressintensity factor for GRP laminates // Composites Scie. and Technol. -2001. - 61, № 8. - P. 1109-1114.

7. Degradation studies of coir fiber/polyester and glass fiber/polyester composites under different conditions / K. Sindhu, K. Joseph, J. M. Joseph, T. V. Mathew // J. Reinforced Plastics and Composites. - 2007. - 26, № 15. - P. 1571-1585.

8. Jelić $M$. Acid and alkali influence on strength and stiffness glass-polyester composite pipes, Final exam work. - Faculty of Technology and Metallurgy, University of Belgrade, 2009.

9. ASTM D 3039-00, Standard test method for tensile properties of fiber-resin composites / Annual book of ASTM standards. -2000.

10. ASTM D 2290-00, Standard test method for apparent hoop tensile strength of plastic or reinforced plastic pipe by split disk method // Annual book of ASTM standards. - 2000.

11. Stamenović M., Putić S., Rakin M., Medjo B. and Čikara D. Effect of alkaline and acidic solutions on the tensile properties of glass-polyester pipes // Materials \& Design. - 2011. - 32, № 4. - P. 2456-2461. 